\title{
WUTHERING HEIGHTS AND KLEIST'S NOVELLEN: ROUSSEAUIAN NATURE, SPONTANEOUS LOVE, INFANCY AND THE PERFORMATIVE SUBVERSION OF THE LAW
}

\author{
WUTHERING HEIGHTS Y LOS RELATOS DE KLEIST: \\ NATURALEZA ROUSSEAUNIANA, AMOR \\ ESPONTÁNEO, INFANCIA Y LA SUBVERSIÓN \\ PERFORMATIVA DE LA LEY
}

\author{
MARÍA VALERO REDONDO \\ Universidad de Córdoba \\ 182varem@uco.es
}

\begin{abstract}
This article analyses the numerous thematic similarities between Wuthering Heights and Heinrich von Kleist's Novellen, especially "Der Findling”. I justify this seemingly unconventional comparison on the basis that both Kleist and Emily Brontë were deeply influenced by Rousseau's works and by his novel, Julie, ou, la Nouvelle Héloïse (1761). The works of both authors share a typically Rousseauian theme: a hostility toward urban civilization and a strong intimacy with nature. This theme is loaded with ideological force and is present in at least four subthemes: the communion with nature, natural childhood, the nature of spontaneous love and the parodic reiteration of the normative community. Thus, although there is no evidence of Brontë's direct knowledge of Kleist's work, I suggest that their shared recourse to a common precursor may account for the uncanny similarity between Kleist's Novellen and Wuthering Heights.
\end{abstract}

Keywords: Wuthering Heights, Kleist's Novellen, “Der Findling”, Rousseau, Romanticism.

\section{Resumen}

Este artículo analiza las numerosas semejanzas argumentales entre Wuthering Heights y los relatos de Kleist, especialmente "Der Findling". Justifico esta 
comparación aparentemente poco convencional partiendo de la base de que tanto Kleist como Emily Brontë fueron profundamente influenciados por las obras de Rousseau y por su novela, Julie, ou, la Nouvelle Héloïse (1761). Así, las obras de ambos autores comparten un tema central típicamente Rousseauniano: una hostilidad exacerbada hacia la civilización urbana y una fuerte conexión con la naturaleza. Este tema central está cargado de fuerza ideológica y, a su vez, está presente en al menos cuatro sub-temas: la comunión con la naturaleza, la naturaleza de la infancia, la naturaleza del amor espontáneo y la reiteración paródica de la comunidad normativa. Aunque no existe evidencia de que Brontë conociera directamente las obras de Kleist, sugiero que la influencia en ambos de un precursor en común podría ser la causa de la llamativa similitud entre los relatos de Kleist y Wuthering Heights.

Palabras clave: Wuthering Heights, los relatos de Kleist, "Der Findling”, Rousseau, Romanticismo.

\section{Heinrich von Kleist and Emily Brontë: A Remarkable Match}

In Fiction and Repetition: Seven English Novels, J. Hillis Miller has claimed that "one of the most obvious characteristics of works of literature is their manifest strangeness" (1982: 18). He does not hesitate to include Wuthering Heights among the selected seven novels as one of these strange works of literature. Indeed, Wuthering Heights has always been analyzed as a 'hapax' or isolated singularity in the history of English literature. The first reactions following its publication in 1847 relegated it to the category of impenetrable mystery. Thus, a reviewer in the Douglas Jerrold's Weekly Newspaper described Wuthering Heights as "a strange sort of book, baffling all regular criticism; yet it is impossible to begin and not to finish it, and quite as impossible to lay it aside afterwards and say nothing about it" (Dunn 2003: 284). More recent scholarship on Wuthering Heights still foregrounds the novel's singularity. Joseph Carroll regards it as "a masterpiece of an imaginative order superior to that of most novels" but "elusive to interpretation" (2008: 241), and Louise Lee highlights the novel's "sui generis appeal" as well as "its singular critical animus" (2016: 81), reinforcing the deep-rooted assumption that Wuthering Heights is an anomalous text or a singularity within the English literary tradition.

Similarly, Heinrich von Kleist's works have been considered a literary singularity in the history of German literature. His Novellen, published in 1810-1811, and his dramatic works have posed the critical problem of indeterminacy. Hence, the poet and editor Christoph Martin Wieland was elated when hearing a reading of Robert 
Guiskard; Goethe, whose support and appreciation Kleist was very eager to obtain, was indifferent to Amphitryon and reacted with aversion to Penthesilea. In a review of Tieck's Dramaturgische Blätter from 1826, Goethe would later express that Kleist provoked in him "Schauder" ["shiver"] and "Abscheu" ["disgust"] (Howe 2012: 1). The fact that only three of Kleist's seven completed dramas were put on stage during his lifetime suggests that these works did not conform to the dominant aesthetic and ethical modes considered appropriate for performance. Recent scholarship has indeed revived Kleist's importance as an Enlightenment figure and has placed his literary oeuvre within the parameters of the Aufklärung in general, alongside Kant in particular (Howe 2012: 1).

These critical reactions suggest that Kleist and Brontë's baffling texts have surpassed the horizon of expectations of both critics and readers since, apparently, there is no hermeneutic frame which would allow them to classify these narratives within a specific literary tradition. I want to argue that the hermeneutic indeterminacy of Wuthering Heights might be due to its indebtedness to the German Novelle, specifically with Kleist's Novellen. Hence, my purpose here is to throw new light on Wuthering Heights by using some of Kleist's Novellen as intertexts —paying particular attention to "Der Findling" ["The Foundling"] in order to detect the common thematic resemblances that these narratives share. The central point in my analysis is that Kleist and Brontë's shared resort to Rousseau may account for the uncanny similarities between their narratives.

My hypothesis, in a nutshell, is that Rousseau's influence on these authors could be the cause of the emergence of such similar narratives. Thus, I will analyze how Rousseau's views on human nature, articulated in Discourse on the Origin of Inequality (1755), Julie, or the New Heloise (1761) and Emile, or On Education (1762), inform Kleist's Novellen and Wuthering Heights, and, more particularly, how these views inspire the development of Nicolo and Heathcliff from a natural state to a social one. These views are expressed in the following themes: nature as a source of genuine feelings and as the basis of human identity; the conflict between spontaneous love and social or moral principles; Nicolo and Heathcliff as natural children who are finally corrupted by an abrupt socialization and by private property; and how the subversive repetition of the law exposes and proves its inaccessibility and malfunction. I will also enrich my analysis with other contemporary theories, like Jacques Derrida's theory of hospitality, Julia Kristeva's concept of the 'abject' or Judith Butler's idea of 'enabling violation'.

Despite the general lack of comparative studies on Kleist and Brontë, these names have very selectively begun to crop up jointly as a remarkable match. Cecil Davies (1978) places Wuthering Heights within the tradition of the German Novelle of the eighteenth and nineteenth century and Carol Jacobs (1989) contextualizes Emily 
Brontë's novel and Kleist's narratives in terms of Romanticism, hermeneutic ambiguity and estrangement. Ralf R. Nicolai (1973) and Andrea Kirchknopf (2004) have drawn the undeniable thematic similarities between Kleist's "The Foundling" and Wuthering Heights. Nicolai assumes that Emily Brontë was familiar with Kleist's work and bases this assumption on "internal evidence" of the similarities between Wuthering Heights and "The Foundling", which, of all of Kleist's Novellen, is undoubtedly the most similar in plot to Emily Brontë's novel (1973: 23). Nicolai analyzes how some characters and episodes in Wuthering Heights seem to have their inspirational source in Kleist's "The Foundling": the similar way in which Nicolo and Heathcliff enter the houses, usurping the place of a dead son; Elvire and Catherine's similar state of mind after the death of Colino and Heathcliff's exile, respectively; Piachi's violent outbursts and Heathcliff and Hindley's brutal quarrels. Andrea Kirchknopf analyzes the resemblances of character constitution in "The Foundling" and in Emily Brontë's novel. She particularly focuses on the foundling characters; social identification; selfidentification through "the other"; the recurring substitution of family members and names; and the recurring illnesses and deaths.

Although these critics put forward a fresh reading of Wuthering Heights, they still evince a lack of critical conviction in their approaches, which do not go beyond "internal evidence" and which, consequently, fail to account for the conspicuous similarities between Kleist's narratives and Emily Brontë's novel. I want to account for these thematic resemblances by arguing that Kleist's and Brontë's resort to a common precursor, Rousseau, may be the cause of the emergence of such similar stories. Besides, I will also enrich the comparison by analyzing the thematic similarities that Wuthering Heights also shares with other Novellen by Kleist, such as "The Earthquake in Chile", "The Marquise of O", "Michael Kohlhaas" and "The Betrothal in Santo Domingo", all of them collected in David Luke and Nigel Reeves' edition, The Marquise of $O$ and Other Stories (2004). Therefore, in this article, I will follow in these critics' footsteps and I will argue that Wuthering Heights - though fairly dissimilar from what had been written in the English literary tradition - was quite consistent with the German tradition of the Novelle and, in particular, with Kleist's narratives. ${ }^{1}$

\section{The Influence of Rousseau on Kleist and Emily Brontë}

There is a cultural context that supports this pairing: the indisputable influence of Rousseau on both Kleist and Brontë. Kleist had read Rousseau in French when he was sent to Berlin after the death of his father, in 1788, and the Rousseauian ideal of communion with nature as the only escape from a decadent feudalism and an 
incipient capitalism had a great impact on his thought (Pérez 1999: 14). Indeed, when he was living in Switzerland, Kleist entertained the Rousseauian idea of going back to nature, and he eventually decided to become a peasant and work the land (Luke and Reeves 2004: 10). It is also unquestionable that the Brontës were deeply acquainted with Rousseau's works. In fact, we find direct evidence that Charlotte Brontë read Rousseau in Shirley, where the Swiss author is the subject of a discussion between the protagonist and Caroline. Although critics like Elizabeth Gargano have pointed out Rousseau's inevitable impact on Charlotte Brontë's works (2004: 786), his influence on Emily Brontë has not been sufficiently or satisfactorily studied.

The English Romantic poets, especially Wordsworth, Byron and Shelley —whom Emily Brontë had surely read ${ }^{2}$ - were also deeply influenced by Rousseau's emphasis upon the preeminence of instinct and feeling. ${ }^{3}$ Thus, Rousseau's emotionalism has permeated British Romantic discourse, which is characterized by a rejection of urban civilization, the celebration of the freedom of nature, the belief in emotional spontaneity and honesty and the conception of literature as an instrument of human unification and purification (Wellek 1958: 141). What I want to stress is that Emily Brontë, whose novel openly engages Romantic motifs, shares common Rousseauian ground with the British Romantics. ${ }^{4}$ Indeed, critics have seen Wuthering Heights as influenced by the incestuous passion in Byron's The Bride of Abydos and Manfred (Lodge 2012: 146) and the character of Manfred —and Byron himself - has always been considered a partial inspiration for Emily Brontë's fatal hero: "Wuthering Heights is Manfred converted to prose romance, and Heathcliff is more like Manfred, Lara, and Byron himself than is Charlotte Brontë's Rochester" (Bloom 2007: 134). Heathcliff's emotional misanthropy and his worship of wild nature is in fact truly Byronic. Apart from this, Shelley's Epipsychidion, with its famous manifesto of free love and its portrayal of metaphysical love, has also been identified as a potential source for the novel (Lodge 2012: 146147). Besides, the Romantic poets' conception of nature as an inherently spiritual place is also a pervasive theme in Emily Brontë's poems and Wuthering Heights.

Emily Brontë adopted the Rousseauian and Romantic conventionalism of representing the inward self as authentic and the external social world as alienating and hostile to authentic selfhood. The inevitable escape from society, the Romantic rejection of mundane conventions, erotic sacrifice and tragic power were all rather common themes in Romantic poetry, but were rarely present in nineteenthcentury English novels. ${ }^{5}$ However, and this is my point here, these Romantic tropes were quite recurrent in Wuthering Heights. Surely, there are few lovers in English fiction who are as unrestrained in their behaviour or in the expression of their passions as Heathcliff and Catherine. Kleist and Brontë assimilated Rousseau's 
dictum that the history of man lies not in books or treaties "but in nature which never lies" and that "everything issuing from nature is true" (Rousseau 2009: 25). The common denominator between Kleist's narratives and Brontë's novel is a Rousseauian hostility toward urban civilization and their closeness to an external nature. "Nature", as the English poets of the eighteenth century understood it, was "a consciousness of our common humanity, of the bond between all people and the unity between man and external nature" (Wellek 1958: 140). ${ }^{6}$ The right of nature predominates. This theme is loaded with ideological force and is present in at least four subthemes: the communion with nature, the nature of infancy, the nature of spontaneous love and the parodic reiteration of the normative community.

\section{Communion with Nature}

One of the most prevalent themes that appears in both Kleist's Novellen and Wuthering Heights is a strong desire to escape from a corrupted civilization which thwarts the characters' more genuine feelings. To this end, these characters try to escape from the nomos to a natural setting which proves to be a site of spiritual immanence, promoting authenticity and a kind of Christian confraternity and revitalizing religious faith. "The Earthquake in Chile" brilliantly emblematizes the conflict between sexual instincts and social, civil and ecclesiastical law. In this novella, Kleist depicts the situation of two victims of an inhuman society, Jerónimo and Josefa, who find their salvation in an idyllic nature, after an earthquake has pulled down the city, paradoxically preventing Josefa's execution for sacrilege and Jerónimo's suicide attempt after having been imprisoned. Ironically, the lovers go back to hell when they decide to go to the only church which the earthquake has spared: they are used as scapegoats and murdered by the people attending the mass. Miller points out that the very laws that have been interrupted by the earthquake return with more strength in the church, instigated by a Judgment Day sermon (1995: 84). For Jerónimo and Josefa, religion is an emotional instinct guided by individual conscience and cut off from all institutions since "[t]rue worship is of the heart" (Rousseau 1991: 287).

To a sharp reader, this plot will bring to mind Rousseau's Julie, or The New Heloise, in which the purity of the love between the protagonists is of a piece with the idyllic nature of the Swiss landscape: "It seemed that this deserted place was meant to be the sanctuary of two lovers who alone had escaped nature's cataclysm" (1997: 425). What is remarkable here is that Saint-Preux, the lover, compares an idyllic place in nature with a sanctuary for two lovers who, like Jerónimo and Josefa, have survived a natural disaster. Both narratives disrupt the opposition between the sacred and the secular, borrowing ideas from Christian theology and 
creating a new response to nature as a source of genuine feelings and as the basis of human identity. Therefore, Kleist's and Rousseau's lovers find "the chief means of self-preservation" in their passions and in nature (Rousseau 1991: 182). The struggle between genuine love and religious and social prejudices is essentially Romantic. Its impossible conflicts make the lovers' final death a dramatic necessity. In "The Marquise of O", nature plays a slightly different role, that of reliever, a catalytic agent that promotes moral relief and a sense of confidence. In this Novelle, Kleist makes use of the Cervantine motif of the fainted woman who is raped and gets pregnant. It makes an ironic allusion to the Christian dogma of the immaculate conception of the Virgin Mary. When her aristocratic family learns about the Marquise's condition intéressante, she loses the support of her parents, on whom she is financially dependent, and is tyrannically banished from the house. The Marquise's only yearning is to prevent her child, whom she considers the most divine of all human beings, from suffering the social stigmatization to which she is condemned. It is when she moves to her country house with her two daughters, leading a life of "perpetual cloistered seclusion" and cut off from an oppressive and despotic society, that she recovers her self-confidence and assumes a Christological persona: "her grief had been replaced by a heroic resolve to arm herself with pride and let the world do its worst" (Kleist 2004: 93).

The Marquise assumes then the Rousseauian psychology of laissez-moi faire, which is experienced in a natural setting and which avoids the hollowness of conventional social opinions and values, giving free reign to an instinctive self-esteem of the natural self (Rousseau 2009: 176). In this case, it is the Marquise's self-love and individual conscience - which is symbolically attained in a natural setting - that is opposed to social prejudice and religious stigmatization. Conscience, for the Marquise, is that "divine instinct" which serves as "guide for a creature ignorant and finite indeed, yet intelligent and free; infallible judge of good and evil, making man like to God!" (Rousseau 1991: 268). Tellingly, passionate love, self-love and individual conscience are always attained in communion with nature in Kleist.

Similarly, Emily Brontë's lovers strongly sympathize with a wild nature which is the site of spiritual immanence. Thus, Heathcliff and Catherine construct a mystic vision of their love that cannot be identified with the Christian Heaven but with the wild and free nature of the fields that surround Wuthering Heights, as can be seen in Catherine's dream, when she claims that she prefers wandering on the moors rather than going to Heaven. Catherine's own paradise is embodied in the savage nature of Wuthering Heights. When she is sick, Catherine states that she feels like an outcast and an exile in a world where she does not belong and, in her delirium, she yearns for her savage and free childhood in the hills of Wuthering Heights: 
Oh, I'm burning! I wish I were out of doors - I wish I were a girl again, half savage, and hardy, and free... and laughing at injuries, not maddening under them! Why am I so changed? Why does my blood rush into a hell of tumult at a few words? I'm sure I should be myself were I once among the heather on those hills... [...] (Brontë 1998: 126)

In Alliston's view, Brontë rewrites the Rousseauian theme of "naive quasi-sibling lovers" living in what she calls "utopias of sympathy" (2002: 141). As in Julie, or the New Heloise, nature in Wuthering Heights is portrayed as a mystical and spiritual place where the lovers can spontaneously relish their love. However, unlike SaintPreux and Julie, Heathcliff and Catherine do not find solace and satisfaction in a peaceful and bucolic nature, but in a violent and inhospitable landscape which responds to Romantic conceptions of the sublime as well as symbolizing the lovers' tormented and unsatisfied love.

\section{Spontaneous Love}

The nature of spontaneous love that threatens moral or social principles and causes disarray appears in Julie, or the New Heloise and in most of Kleist's Novellen and Wuthering Heights. When Nelly returns to the house after having been expelled, she hears that Heathcliff and Catherine have suddenly become "very thick" (Brontë 1998: 36). ${ }^{7}$ This is indeed the representation of the relation between Eros and Psyche, who are frequently represented as embracing or gazing at each other. This image captures the childlike unconscious state of both infant innocence and sexual unconsciousness (Doody 1997: 364). This infant innocence ends when Catherine acquires a social conscience after her short stay with the Lintons: "Why, how very black and cross you look! And how - how funny and grim! But that's because I'm used to Edgar and Isabella Linton" (Brontë 1998: 52). Later, she would recognize to a bewildered Nelly that "[i]t would degrade [her] to marry Heathcliff now" (80).

According to Rousseau, "the more violent the passions, the more necessary are the laws to contain them", but it is also true that the disorders and crimes caused by these passions clearly disclose the inadequacy of these very laws (2009: 48). Thus, it would be convenient to examine whether or not civil, social and moral laws cause these disorders "for then, if the laws were capable of suppressing such disorders, the very least that one would demand of them is that they should put a stop to an evil that would not exist without them" (48). In Wuthering Heights, it is precisely Catherine's newly acquired social conscience and her incorporation into the "civilized world" that trigger the tragedy in the novel since "Eros is —and should always be-lawless" (Doody 1997: 360). Similarly, in Kleist's narratives 
and in Julie, the application of the law - whether it is the law of the father, the social law or the moral law- causes an erotic or anomic implosion.

Kleist's lovers are in some way bound to confront civil, social and moral laws in order to be together. In "The Earthquake in Chile", Josefa never renounces her lover and even becomes pregnant by him whereas in "The Betrothal in Santo Domingo", Toni betrays her mother and her people and falls in love with the white man in whose murder she is supposed to be assisting. She tries to save the stranger and to elope with him in order to marry him in Europe. In Rousseau's Julie, or the New Heloise, it is not only the Law of the father that interposes between SaintPreux and Julie but an inner desire to fulfill ethical norms and expectations. Thus, Julie accepts a socially enforced marriage with Wolmar in a desperate attempt to become the personification of virtue: "I felt my heart was only made for virtue", she writes, "and that it could not be happy without it" (Rousseau 1997: 282). Julie willingly renounces her true love, Saint-Preux, whom her father abhors, in order to satisfy her father's — and society's - expectations. Eventually, her ethic of personal will ends up becoming an ethic of constraint (Hall 1961: 30): "Dear friend, do you not know that virtue is a state of war, and that living in it means one always has some battle to wage against oneself?" (Rousseau 1997: 560). It is always the imposition of the Law that brings calamity. Therefore, Josefa is forced into a convent for refusing to renounce her lover and condemned to death for fornication and sacrilege, whereas Jerónimo is also imprisoned and plans to commit suicide. Toni is shot to death by her lover, who believes her to be a traitor, and Julie - like Catherine - ends up immolating herself in a socially enforced marriage with a man she does not love. What all these narratives betray is a common Rousseauian principle: the ethics of authenticity are above rational, moral or social principles.

The erotic dimension and the emotional idyll of the lovers in Wuthering Heights, "The Betrothal in Santo Domingo", "The Earthquake in Chile" and Julie confer on these narratives a quasi-religious dimension. This is symbolically borne out at the end. Thus, whereas Heathcliff and Catherine are said to have acquired a spectral existence, Mr. Strömli literarily monumentalizes Gustav and Toni by erecting two statues representing them in his garden, and Jerónimo and Josefa's transcendental love finds its sacralization in their son, Felipe, who miraculously escapes from Master Pedrillo's violent massacre and is adopted as a surrogate son by Don Fernando and Doña Elvira. In Rousseau's novel, Julie, on her death-bed, finally acknowledges that she still loves Saint-Preux and expresses her desire to be reunited with him in Heaven: "Nay, I leave thee not, I go to await thee. The virtue that separated us on earth shall unite us in the eternal abode. I die in this flattering expectation" (Rousseau 1997: 610). The mystical resolution of these narratives finally cancels the possibility of an alternative community of (adulterous) lovers 
who challenge and confront collectively sanctioned norms. And yet, even if they do not fulfil this narrative possibility, these narratives unleash a disruptive energy. Consequently, behind these transcendental implosions, there is a subversive energy that timidly hints at an alternative, more authentic community because, as Maurice Blanchot put it, a community of lovers is that "antisocial society or association", which, no matter whether the lovers want it or not, "has as its ultimate goal the destruction of society" (1998: 48).

\section{Children of Nature}

Thematically, no novella is more analogous to Wuthering Heights than "The Foundling". Both narratives have as hero —or villain — a foundling of unknown origins who shares many traits with Rousseau's description of the natural child in Emile, or On Education: they are both robust and vigorous children of nature who have not acquired the art of rhetoric and who are finally corrupted by an abrupt socialization and by the lures of private property. Both stories begin in a strikingly similar manner: a father who, after the death of his son, adopts another in his place. Like Mr. Earnshaw, Piachi finds an orphan, Nicolo, during a business journey. Both Nicolo and Heathcliff have an ambiguous nature as both fiend and angel. Thus, when Piachi asks the doctors if he is allowed to take Nicolo, they answer that he is "the son of God" and that he "would be missed by nobody" (Kleist 2004: 271). Nicolo is also depicted as cracking and eating nuts, a habit associated with the devil in folklore traditions of superstition (Kirchknopf 2004: 36). Mr. Earnshaw's first words about Heathcliff are equally ambiguous: "See here, wife! I was never so beaten with anything in my life: but you must e'en take it as a gift of God; though it's as dark almost as if it came from the devil" (Brontë 1998: 34). Both Nicolo and Heathcliff have a dark physiognomy and a hostile attitude. Nicolo "was handsome in a strangely statuesque way; his black hair hung down from his forehead in simple points, overshadowing a serious, wise-looking face which never changed its expression" (Kleist 2004: 271), and Heathcliff is first described by Nelly as "a dirty, ragged, black-haired child" (Brontë 1998: 35).

These two foundlings are children without provenance, illegitimate children out of the silences of fiction who bear the physical and psychic marks of terrible traumas. Thus, Nicolo has recently lost his parents and has contracted the plague. He begs Piachi "in the name of all the saints to let him come with him and not leave him behind to perish in the town. As he spoke he clasped the old man's hand, pressed it and kissed it and covered it with tears" (Kleist 2004: 270). Similarly, Mr. Earnshaw finds Heathcliff "starving" and "houseless" in the streets of Liverpool and, since "not a soul knew to whom it belonged", he decides to take "it" home 
with him. It is a striking difference that, whereas Nicolo begs and cries, Heathcliff should do neither. Tellingly, Heathcliff does not need to resort to these subterfuges in order to move his benefactor.

Both Nicolo and Heathcliff have been hardened by their shared infancy as vagrant and nomadic children who belong nowhere. According to Rousseau, when beasts are domesticated, they lose energy, strength and spiritedness, and the same is true of human beings themselves; when they become sociable and domesticated, they also become weak, fearful and submissive (2009: 31). Hence, while Piachi's refined and vulnerable son, the eleven-year-old Paolo, became infected with the plague and died within three days, the robust Nicolo recovered his full health in the hospital. Also, Heathcliff is described by Nelly as a "sullen, patient child; hardened, perhaps, to ill-treatment" who would "stand Hindley's blows without winking or shedding a tear" (Brontë 1998: 36). When the children fell ill of the measles, Heathcliff "was as uncomplaining as a lamb" and would "give little trouble" (36). Darwin's evolutionary theory of natural selection is at work in both cases, since "as some individuals are produced than can possibly survive, there must in every case be a struggle for existence, either one individual with another of the same species, or with individuals of distinct species, or with the physical conditions of life" (Darwin 2008: 88). Nature has taught Nicolo and Heathcliff to be robust and sturdy and to "bear pain bravely" (Rousseau 1991: 48). It is society and nurture which later "debase the heart and make us afraid to die" (48).

As uncivilized children, Nicolo and Heathcliff do not master the art of language or, if they do, they prefer to remain uncommunicative. The word "infant" comes from the Latin infantem, "young child, babe in arms", a noun use of the adjective meaning "not able to speak", from in- "not" and fans, present participle of fari "to speak". Besides, communication impairment and selective mutism are always related to isolation and anti-social behaviours. While Nicolo sits in a corner, "uncommunicative and absorbed in himself, with his hands in his trouser pockets, looking pensively and diffidently out of the windows of the carriage as it sped along" (Kleist 2004: 272), Heathcliff can only stare around and repeat "over and over again some gibberish that nobody could understand" (Brontë 1998: 34). Both foundlings are introduced as a kind of "blank slate" with respect to their previous lives, and they appear to have lost or never fully learned the art of language (Staten 2014: 135). Their initial communication failure is indeed a sign of the unspeakable now verbalized, that is, of the trauma and damage that has been done to them during infancy.

Nicolo and Heathcliff only possess "a pathetic or expressive voice" which serves "as the language of passions" (Rousseau 1991: 119). They do not need to master rhetoric because they are indifferent to everyone but themselves; "they take no 
interest in anyone and they do not pretend to take such an interest; they are less deceitful than others" (Rousseau 1991: 194). As vagrant and forsaken children who have no relations with others or do not need them, "the necessity or indeed the possibility of language is inconceivable, if it could be done without" (Rousseau 2009: 38). When they are taken into the house of their benefactors, both Nicolo and Heathcliff are uncivilized children and all they know at that time they have learned from experience (Rousseau 1991: 225). This possibly explains their communication impairment and the fact that they have more vigour, strength and courage than Paolo or Hindley. It is due to their abrupt and violent socialization into a family that they learn "the force of the arts of persuasion" (Rousseau 1991: 225 ) and are finally degenerated by private property. Thus, Nicolo and Heathcliff alienate themselves from nature and become both destructive and egotistical adults.

\section{The Performative Subversion of the Law}

The subversion of the normative community is pointedly present in Kleist's "Michael Kohlhaas" and "The Foundling", and in Emily Brontë's Wuthering Heights. For Miller, no other story by Kleist is more dominated by legal questions than "Michael Kohlhaas" (1995: 85). Kohlhaas is a wealthy and honorable man with a strong sense of justice [Rechtgefühl] that will turn him "into a robber and a murderer" and make him "one of the most honorable as well as one of the most terrible men of his age" (Kleist 2004: 114). After having his two horses unlawfully detained and ill-treated on his journey to Dresden, he tries to take legal action but fails because of corruption in the administration, which Hamlet wisely called "the insolence of office" (Shakespeare 2008: 97). Frustrated, Kohlhaas decides to take the law into his own hands. He hires an armed band, pursues Junker von Tronka and burns down his castle and part of Wittenberg. During his interview with Martin Luther, he defends himself stating: "I call that man an outcast [verstoßen] $[\ldots]$ who is denied the protection of the law! [...] Whoever withholds it from me drives me out into the wilderness among savages [unter den Wilden der Einöde]" (Kleist 2004: 152).

"Michael Kohlhaas" proves the failure of the law and illustrates how "an affront to the law is repaired by a repetition of an affront to justice" (Miller 1995: 103). This novella establishes, then, the unavailability and the failure of law since, quite ironically, an attempt is made to repair an affront to the law by violent and numerous affronts to justice. Kleist cunningly suggests here that the operation of the legal system is undermined by the power interest and the selfishness of those who dispense justice. He also examines the intrinsic flaws of bureaucratic law, 
problematizing the idea of personal responsibility in a way that makes it difficult to blame someone unequivocally. Like Michael Kohlhaas, Heathcliff takes the law into his own hands but, while Kohlhaas proves to have a subversive and reformist ideology, Heathcliff is not moved by a utopian will to reform or expose the unkindness of the legal system. He is just a possessive individualist who has been forced to understand the ways of the world. When he has finally achieved all his carefully planned purposes, Heathcliff, instead of articulating a powerful reformist dictum, expresses his despondency:

\footnotetext{
"It is a poor conclusion, is it not?" he observed, having brooded awhile on the scene he had just witnessed: "an absurd termination to my violent exertions? I get levers and mattocks to demolish the two houses, and train myself to be capable of working like Hercules, and when everything is ready and in my power, I find the will to lift a slate off either roof has vanished!" (Brontë 1998: 323)
}

Both Michael Kohlhaas and Heathcliff want to take revenge on the institutions, the law, the state and society; and both of them are ultimately in their rebellion driven to despair. The key difference between them is that whereas Kohlhaas exerts a conscious revolt against the law, Heathcliff's rebellion is not driven by revolutionary or reformist energies; on the contrary, Heathcliff's revenge is more rudimentary and instinctive since he uses the law for his aims. Nevertheless, even if Heathcliff seldom expresses a subversive ideology, Emily Brontë does establish an understated game of subversion. Unlike Kohlhaas, Heathcliff does not return to a state of nature. $\mathrm{He}$ frames, rather, a new social contract. He has assimilated the social system, and wishes merely to reduplicate its very laws and contracts. But in doing so, he - though unconsciously - proves the unavailability and failure of the law, inaugurating the law of absence. Ironically, the repetition of the law becomes itself an affront to justice. Both "Michael Kohlhaas" and Wuthering Heights prove Rousseau's theory that the origin of society and of laws destroyed natural freedom irreversibly, set down the law of property and inequality, made skillful usurpation into an irreversible right, "and henceforth subjected, for the benefit of a few ambitious men, the human race to labour, servitude, and misery" (Rousseau 2009: 69).

The subversion of the law of property and legal inheritance also triggers the action of "The Foundling". Nicolo, the adoptee, usurps the place of the legitimate son in the family, Paolo, whereas Heathcliff is named after a dead brother of Catherine. Both children pollute the well-ordered and happy existence of the wealthy Roman Piachi and the Earnshaw family, respectively. We can see that Nicolo tries to accommodate to the normative community by complying with a socially accepted marriage with Constanza Parquet, leaving behind his illicit relationship with Xaviera Tartini. Besides, he is introduced into the family business and, subsequently, becomes the legal heir of all of Piachi's possessions: 
when Piachi reached the age of sixty he took for Nicolo the final step that a benefactor could take: he gave him legal possession of the entire fortune on which his property business rested, retaining only a small capital for himself, and withdrew with his faithful, virtuous Elvira, whose worldly wishes were few, into retirement. (Kleist 2004: 273)

Nicolo's marriage to Elvira's niece, his incorporation into the labour market and the inheritance of Piachi's possessions are performative acts within the judicial and legal frame. The first one turns him into a husband, the second into a worker and the third into a legal heir, overlapping titles that sustain the family and the three basic pillars - matrimony, patrimony and genealogy - lending support to the traditional community itself. Heathcliff's assimilation of the normative community is more violent and sadistic. He seduces, abducts and marries Isabella in order to take revenge on Linton. Then, he sadistically inflicts his vengeance on Hindley's son - who is his own surrogate - and to Cathy, forcing the latter to marry his dying son, Linton Heathcliff, in order to inherit the two properties, Wuthering Heights and Thrushcross Grange: "I want the triumph of seeing my descendant fairly lord of their estates; my child hiring their children to till their fathers' lands for wages" (Brontë 1998: 234).

But not only do Nicolo and Heathcliff subvert the law of property and legal inheritance, they also transgress the implicit social and moral laws of hospitality. Both constitute two figures of alterity which threaten and destabilize the organic community of blood, birth, social status and genealogy of the family. In Jacques Derrida's theory of hospitality, they would be the encroaching satellites of the family system, the domestic intruders who "shake up the threatening dogmatism of the paternal logos" (Derrida and Dufourmantelle 2000: 5). Nicolo is charitably admitted to the house as a surrogate son but — like Heathcliff - he ends up as a legitimate owner, even forcing Piachi to leave the house, "for he, Nicolo, was now its owner by deed of gift and he would defend his title to it against all comers" (Kleist 2004: 285). Derrida argues that it is the master of the house, the chief guardian, who lays down the laws of hospitality (Derrida and Dufourmantelle 2000: 149). Absolute hospitality requires, then, that the master of the house opens up his home and gives place to the outsider, to the foreigner or to the absolute other without asking anything from them (25). According to Derrida, what distinguishes a guest from a parasite is the obedience to moral and social law. For a newcomer to be received as a guest, he has to be submitted to a limiting authority. Both Nicolo and Heathcliff have been welcomed as absolute and unknown aliens who have acquired the rights of guests. Their family duties are the entrance into the business market — and a respectable marriage in Nicolo's case - and obedience to the rules of legal inheritance. 
These two guests cannot help their satanic and vindictive nature. Nicolo is described by Kleist as an "infernal scoundrel" (2004: 285) and is compared to Tartuffe (285), whereas Heathcliff reprises the role of the diabolical self of Gothic tradition, "dark almost as it came from the devil" (Brontë 1994: 38), an "imp of Satan" (38) with a "devilish nature" (172), a "fierce, pitiless, wolfish man" (102), a "ghoul" or a "vampire" (330). As children of nature, they were guided by their instincts and passions and yielded impetuously to the "impulses of human feeling" (Rousseau 2009: 47) but once they are taught the importance of private property and wealth, they pass from a natural state (childhood and innocent primitivism) to a social one (adulthood and experience).

As a result, Nicolo and Heathcliff become avaricious and corrupt. They end up biting the hand that feeds them, which is one of the greatest transgressions of hospitality. When a guest encroaches on his host's authority, he becomes a hostile subject and the host risks becoming his hostage (Derrida and Dufourmantelle 2000: 53). By the same logic, Nicolo and Heathcliff have become hostile subjects to both Piachi and Hindley, respectively, who, therefore, have turned into hostages, victims of their original guests. Both foundlings display an exceptional mastery of the law of inheritance. Thus, the government issues a decree giving Piachi's property to his foster son and Nicolo knows how to take advantage of this. Similarly, Heathcliff tries to perpetuate both his genealogy and his landed property by marrying Isabella Linton, having a son with her and arranging the marriage of his son to Catherine Linton, so that the whole property of the two families is controlled by him.

Ironically, the destruction of this traditional community is performed through the parodic usurpation of the normative conventions that govern it. Both Nicolo and Heathcliff are 'abjects' in Kristeva's terminology, beings who do "not respect borders, positions, rules", and "disturb identity, system, order" (1982: 4). They destabilize the normative community, not standing out as completely different but challenging it from within, performing what Judith Butler -borrowing from Gayatri Spivak - would call 'an enabling violation' since acts of disobedience must always take place within law. Although individuals are always implicated in these relationships of power, they are at the same time enabled by them, not merely subordinated to the law (Butler 1993: 79). Nicolai mentions that, in both narratives, "the villain enjoys protection by the law" (1973:25), but it is Eagleton, in Myths of Power: A Marxist Study of the Brontës (1975), who develops this argument further: "Heathcliff is a dynamic force which seeks to destroy the old yeoman settlement by dispossessing Hareton; yet he does this partly to revenge himself on the very Linton world whose weapons (property deals, arranged marriages) he deploys so efficiently" (2005: 112). 
Both Nicolo and Heathcliff make a parody of the legal and social contracts which sustain society, but the result is neither comic nor satirical; it is subversive and disruptive. They come through as parasites which throw into disarray the family system and prove the inauthenticity of the three fundamental pillars - matrimony, patrimony and genealogy - that sustain the endurance of the traditional community. This parodic subversion exposes the usurpatory origin of the social classes; it represents the ethnic otherness which perturbs the purity of lineage, and stresses the porosity between the different social classes, readjusting the social system. These two adoptees have proved how paradoxical and corrupting the law of inheritance is: it ironically legitimates usurpation.

To conclude, I hope to have shown that, although there is no direct evidence that Emily Brontë read Kleist's narratives, there is a strong thematic connection between Kleist's Novellen and Emily Brontë's Wuthering Heights. This striking connection may have its origin in Rousseau's ideas, which were in vogue in the last decades of the eighteenth century and which influenced the works of both Kleist and Emily Brontë: a hostility toward a corrupt civilization which thwarts the characters' most genuine feelings, and the view of nature as a source of new feelings and as the basis of human identity. This theme is present in four subthemes that appear in most of Kleist's narratives and in Wuthering Heights: a spiritual union with nature; the nature of spontaneous love; the child as a source of natural and spontaneous feeling; and the subversive repetition of the normative community, which proves that laws destroy natural freedom irreversibly and legitimate property, inequality and usurpation.

\section{Notes}

1.Two of Kleist's Novellen had been translated into English in Charles Whiting's collection of German tales. This edition, dated 1844, includes a translation of "Michael Kohlhaas" and of "St. Cecilia; or, the Power of Music" by John Oxenford. This has been, to the best of my knowledge, overlooked by Brontë critics. Besides, Kleist's Novellen were translated into French in 1830 by Adrienne I. and Joël Cherbuliez. We know that Emily Brontë was quite proficient in French and that she had some knowledge of German (Lonoff 2012: 110). However, I cannot ascertain whether or not Emily Brontë was acquainted with Whiting's edition, whether she was able to read Kleist's prose in German or whether she read the French translation of the Novellen. And yet, the fact that Wuthering Heights has many important intertextual similarities with Kleist's "The Foundling" justifies and reinforces the conjecture that Emily Brontë may have been acquainted with Kleist's work.

2 . In her letters to her lifelong friend, Ellen Nussey, Charlotte Brontë expresses her deep admiration for Byron, Wordsworth and Southey. In addition, the sisters sent complimentary copies of their poems toThomas de Quincey, Hartley Coleridge, Ebenezer Elliot, 


\section{Wuthering Heights and Kleist's Novellen}

John Gibson Lockhart, Alfred Tennyson, and William Wordsworth (Brontë 2010: 85).

3. There are several critical accounts of the legacy of Rousseau in British Romanticism. Henri Roddier (1950) reviews Rousseau's reception in eighteenth-century England and analyzes his undeniable influence on William Blake, William Godwin, Edmund Burke and Charlotte Smith, whereas Joseph Texte (1899) and Jacques Voisine (1956) focus on Rousseau's powerful impact on Byron, Shelley and Hazlitt among others. More recent Anglophone equivalents have also appeared. Edward Duffy's Rousseau in England (1979) examines Rousseau's reception in England and his influence on Wordsworth, Coleridge and Shelley, and Russell Goulbourne and David Higgins' JeanJacques Rousseau and British Romanticism (2017) offers a comprehensive analysis of Rousseau's influence on British Romanticism.

${ }^{4}$. Leaving aside the exceptional case of Sir Walter Scott, whose novels are often, and perhaps rightly, called Romantic, there are cases of nineteenth-century novelists strongly influenced by Romantic poetry, like Charles Dickens's David Copperfield (1850) which is full of Wordsworthian overtones - or George Eliot's Daniel Deronda (1876) - which includes several epigraphs by, and references to, Wordsworth, Coleridge, Byron, Shelley and Keats.

${ }^{5}$. There are, however, exceptions. We find a myriad of Romantic motifs in some nineteenth-century novels, such as Sir Walter Scott's The Bride of Lammermoor (1819) which Emily Brontë had surely read - with its portrayal of a tragic love affair, or Charles Maturin's Melmoth the Wanderer (1820), full of Gothic excesses. The case is different with eighteenth-century English novels, some of which could have influenced Emily Brontë. Thus, William Godwin's Caleb Williams (1794) or Matthew Lewis's The Monk (1796) share many (Gothic) motifs with Wuthering Heights, such as revenge, extreme violence, incarceration, and insanity.

${ }^{6}$. This is central in Wordsworth's poetry. In poems such as "The Old Cumberland Beggar" and Resolution and Independence, he celebrates the spirit of the individual living in communion with nature and away from the corrupt city (Carter and McRae 2009: 205).

7. Shelley's lines in Epipsychidion and his conception of Platonic love resonate in this passage: "One passion in twin-hearts, which grows and grew, / Till like two meteors of expanding flame,/ Those spheres instinct with it become the same" (Shelley 1994: 67).

\section{Works Cited}

Aluston, April. 2002. "Transnational Sympathies, Imaginary Communities". In Cohen, Margaret and Carolyn Dever (eds.) The Literary Channel: The Inter-National Invention of the Novel. Princeton: Princeton U.P.: 133-148.

BLANCHOt, Maurice. 1998. The Unavowable Community. Trans. P. Joris. Barrytown: Station Hill.

Bเoom, Harold. (2004) 2007. Novelists and Novels. New York: Checkmark Books.

BRontË, Charlotte. (1932) 2010. Charlotte Brontë: Selected Letters. Oxford: Oxford U.P.
BRontË, Emily. (1847) 1998. Wuthering Heights. Oxford: Oxford U.P.

ButLen, Judith. 1993. Bodies that Matter: On the Discursive Limits of Sex. London: Routledge.

CArroll, Joseph. 2008. "The Cuckoo's History: Human Nature in Wuthering Heights". Philosophy and Literature 32: 241-257.

CARTER, Ronald and John McRae. 2009. The Routledge History of Literature in English: Britain and Ireland. New York: Routledge.

DARWIN, Charles. (1859) 2008. On the Origin of Species. New York: Pocket Books. 


\section{María Valero Redondo}

DAVIeS, Cecil. 1978. "Art within a Tradition: Wuthering Heights and the German Novelle". Brontë Society Transactions 17 (3): 202-203.

Derrida, Jacques and Anne Dufourmantelle. 2000. Of Hospitality: Anne Dufourmantelle Invites Jacques Derrida to Respond. Trans. R. Bowlby. Stanford: Stanford U.P.

Doody, Margaret Anne. 1997. The True Story of the Novel. New Brunswick: Rutgers University.

DufFy, Edward. 1979. Rousseau in England: The Context for Shelley's Critique of the Enlightenment. Berkeley: University of California Press.

DunN, Richard J. 2003. "Backgrounds and Contexts". In Dunn, Richard J. (ed.) Wuthering Heights. New York: Norton: 259-351.

Eagleton, Terry. (1975) 2005. Myths of Power: A Marxist Study of the Brontës. London: Palgrave Macmillan.

Gargano, Elizabeth. 2004. "The Education of Brontë's New Nouvelle Héloïse in Shirley". Studies in English Literature 44 (4): 779-803.

Goulbourne, Russell and David Higgins. 2017. Jean-Jacques Rousseau and British Romanticism: Gender and Selfhood, Politics and Nation. London: Bloomsbury Publishing.

HaLL, Gaston H. 1961. "The Concept of Virtue in La Nouvelle Heloise". Yale French Studies 28: 20-33.

Howe, Steven. 2012. Heinrich Von Kleist and Jean-Jacques Rousseau: Violence, Identity, Nation. New York: Camden House.

JAcoBs, Carol. 1989. Uncontainable Romanticism: Shelley, Brontë, Kleist. Baltimore: Johns Hopkins U.P.

KIRCHKNOPF, Andrea. 2004. "Character Constitution in Heinrich von Kleist's Der Findling and Emily Brontë's Wuthering Heights". The AnaChronis T 10: 31-45.

KLEIST, Heinrich. (1811) 1830. Michel Kohlhaas, le Marchand de Chevaux et Autres Contes. Trans. A.I. and J. Cherbuliez. Paris: Hachette Livre.

KLeIST, Heinrich. (1811) 2004. The Marquise of $O$ and Other Stories. Trans. D. Luke and N. Reeves. New York: Penguin.
Kristeva, Julia. 1982. Powers of Horror: An Essay on Abjection. Trans. L.S. Roudiez. New York: Columbia U.P.

LEE, Louise. 2016. "Wuthering Heights". In Hoeveler, Diane Long and Deborah Denenholz Morse (eds.) A Companion to the Brontës. Chichester: John Wiley \& Sons: 81-100.

LodGE, Sara J. 2012. "Literary Influences on the Brontës". In Thormählen, Marianne (ed.): 143-150.

LonOFF, Sue. 2012. "The Brussels Experience". InThormählen, Marianne (ed.): 107-114.

LuKe, David and Nigel Reeves. 2004. "Introduction". The Marquise of $O$ and Other Stories, by Heinrich Kleist. Trans. D. Luke and N. Reeves. New York: Penguin: 7-49.

MilleR, Joseph Hillis. 1982. Fiction and Repetition: Seven English Novels. Cambridge: Harvard U.P.

Miller, Joseph Hillis. 1995. Topographies. Stanford: Stanford U.P.

NicolAl, Ralf R. 1973. "Wuthering Heights: Emily Brontë's Kleistian Novel". South Atlantic Bulletin 38 (2): 23-32.

Pérez, Ana. 1999. "Introducción". In Pérez, Ana (ed.) Narraciones. Trans. J. Mateos. Madrid: Cátedra: 9-85.

Roddier, Henri. 1950. J.-J. Rousseau en Angleterre au XVIIle siècle. Paris: Boivin.

Rousseau, Jean-Jacques. (1762) 1991. Emile, or On Education. Trans. A. Bloom. Harmondsworth: Penguin.

Rousseau, Jean-Jacques. (1761) 1997. Julie, or the New Heloise: Letters of Two Lovers Who Live in a Small Town at the Foot of the Alps. Trans. P. Stewart and J. Vaché. Dartmouth: Dartmouth College Press.

Rousseau, Jean-Jacques. (1755) 2009. Discourse on the Origin of Inequality. Trans. F. Philip. Oxford: Oxford U.P.

ShaKespeARe, William. (1603) 2008. Hamlet. Oxford: Oxford U.P.

Shelley, Percy Bysshe. (1810-1819) 1994. The Complete Poems of Percy Bysshe Shelley. New York: Modern Library. 
Staten, Henry. 2014. Spirit Becomes Matter. Edinburgh: Edinburgh U.P.

TEXTE, Joseph. (1899) 1970. Jean-Jacques Rousseau et les origins du cosmopolitisme littéraire: Étude sur les relations littéraires de la France et de l'Angleterre. Genève: Slatkine Reprints.

ThormäHLEN, Marianne. (ed.) 2012. The Brontës in Context. Cambridge: Cambridge U.P.

VoISINE, Jacques. 1956. Jean-Jacques Rousseau en Angleterre à l'époque romantique: les écrits autobiographiques et la légende. Paris: Didier.

Wellek, René. 1958. A History of Modern Criticism: 1750-1950, vol. 2. Yale:Yale U.P.

WHITING, Charles. (ed.) 1844. Tales from the German, Comprising Specimens from the Most Celebrated Authors. Trans. J. Oxenford. London: Chapman and Hall.

Received: 22/11/2019

Accepted: 27/04/2020 